\title{
A significant antihypertensive effect of Holarrhena floribunda supported by an exploratory phytochemical study
}

\author{
Kafui Kpegba ${ }^{1}$, Etonam Tété Kondo ${ }^{1}$, Oudjaniyobi Simalou ${ }^{1 *}$, Komlatsè Togbenou ${ }^{2}$, Pakoupati Boyode ${ }^{1}$, Outéndé \\ Toundou $^{1}$, Nagba Yendoubé Gbandjaba ${ }^{1}$, Amegnona Agbonon ${ }^{2}$, Messanvi Gbeassor ${ }^{2}$ \\ ${ }^{1}$ Laboratoire de Chimie Organique et des Substances Naturelles (Lab COSNat), Faculté des Science, Université de Lomé, 01 BP 1515 Lomé 01 , Lomé- \\ Togo \\ ${ }^{2}$ Laboratoire de Physiologie et de Pharmacologie, Faculté des Science, Université de Lomé ; 01 BP 1515 Lomé 01, Lomé-Togo
}

\section{A R T I C L E IN F O}

Article Type:

Original Article

\section{Article History:}

Received: 2 March 2018

Accepted: 27 June 2018

\section{Keywords:}

Holarrhena floribunda

Phytochemical screening

Antioxidant activity

Antihypertensive activity

\begin{abstract}
A B S T R A C T
Introduction: Holarrhena floribunda (G.Don) T.Durand \& Schinz is a tree that can grow up to $25 \mathrm{~m}$ with white latex in its organs. The bark of this plant is commonly used in traditional medicine to treat dysentery, diarrhea, diabetes, malaria, and high blood pressure. In this study, phytochemical groups were widely investigated on trunk bark as well as on leaves of $H$. floribunda harvested in Danyi (Togo). Antioxidant activity and antihypertensive properties of the plant extracts were also evaluated on sound guinea pigs.

Methods: The hydro-ethanolic extract of the trunk bark was prepared and antioxidant activity was evaluated via the DPPH radical-scavenging and the ferric-reducing antioxidant power (FRAP) methods, and via the determination of the total phenolics content. This hydro-ethanolic extract was used to assess the plant extract effect on blood pressure of sound guinea pigs.

Results: So, phytochemical screening revealed that $H$. floribunda contained most of the phytochemical groups. The $50 \%$ inhibitive concentration of that extract by DPPH was 29.80 $\pm 0.001 \mu \mathrm{g} / \mathrm{mL}$. The equivalent of $\mathrm{Fe}^{2+}$ by FRAP was $1009.9 \pm 0.6 \mu \mathrm{mol} / \mathrm{g}$ of dry extract. The content of phenolic compounds was $139 \pm 0.053 \mathrm{mg} \mathrm{GAE}$ (gallic acid equivalents)/g of dry extract. Intravenous injection of the extract $(10,20,40,80 \mathrm{mg} / \mathrm{kg})$ via the invasive method in guinea pigs under normal strain caused a decrease in diastolic blood pressure, systolic blood pressure, and so in mean arterial pressure (MAP) by dose cumulative and time-dependent. Conclusion: The results show that hydro-ethanolic extract of $H$. floribunda trunk bark has antihypertensive and antioxidant properties. This might be the reason for the use of that extract for the treatment of hypertension in traditional medicine.
\end{abstract}

Implication for health policy/practice/research/medical education:

Holarrhena floribunda trunk bark exhibited antihypertensive and antioxidant properties, supporting its use for the treatment of hypertension in traditional medicine. So, more investigations are needed for identification of the active compounds in Holarrhena floribunda ethanolic extract involved in antioxidant and antihypertensive activities.

Please cite this paper as: Kpegba K, Kondo ET, Simalou O, Togbenou K, Boyode P, Toundou O, et al. A significant antihypertensive effect of Holarrhena floribunda supported by an exploratory phytochemical study. J Herbmed Pharmacol. 2018;7(3):160-167. doi: 10.15171/jhp.2018.27.

\section{Introduction}

Cardiovascular diseases (CVD) are pathologies that affect the heart and blood vessels. They are the main cause of deaths in the world (1). More than three-quarters of deaths in low- and middle-income countries are due to CVD (2). In Togo, the situation of CVD is of great concern while their incidence is not fully known (3). Risk factors for CVD include poor nutrition and physical inactivity, smoking, oxidative stress, heavy drinking, diabetes, hyperlipidemia, and hypertension. Indeed, hypertension is a chronic pathology that constitutes a real public health problem with a global prevalence in the world for adults estimated at $26.4 \%$ in 2000 (972 million people including 639 million in resource-limited countries) and could reach $29 \%$ by 2025 ( 1.56 billion of peoples) (4). The conventional treatments of hypertension require synergy of several 
classes of antihypertensive agents; even so none of those treatments definitely cured this pathology. Moreover, the high cost when facing the treatment of hypertension with conventional drugs makes it hardly affordable for common peoples. For that, common people prefer using traditional medicines. Indeed, some studies have shown the positive effects of antioxidants from plants as good agents for the prevention of hypertension diseases (5). It is known that several plants are used in traditional medicine to treat high blood pressure (6). Holarrhena floribunda is one of those species which natural ecological zone covers many African countries namely Togo, Senegal, Guinea-Bisseau, Guinea, Mali; Burkina Faso, Sierra Leonne, Liberia, Ivory Coast, Ghana, Benin, Nigeria, Chad, Cameroon, Gabon, Congo, Central Africa. The many uses of $H$. floribunda in traditional medicine in those African countries include the treatment of dysentery, diarrhea, fever, snake bite, infertility, venereal disease, diabetes, hypertension, and malaria $(7,8)$. So, the present study aimed mainly the assessment of the antihypertensive effects of the ethanolic extract of the trunk bark of $H$. floribunda. For that, the phytochemical groups of the leaves and the trunk bark were firstly investigated. Then, the anti-radical activity and the effect on the blood pressure of normal strained guinea pigs of the trunk bark hydro-ethanolic extract were evaluated.

\section{Materials and Methods}

General information

Optical densities (absorption spectra) were determined on a Shimadzu UV-1601PC spectrophotometer. Samples were weighted using a Sartorius lab instruments balance with maximum weight of $1000 \pm 0.01$ g. Evaporation was carried out on an R-100 BÜCHI Rotavapor. An electric shredder and a transducer connected to Biopac System (Model MP100, Harvard Apparatus) allowed the assessment of extract effects on sound guinea pigs blood pressure. Analytical grade solvents and all others materials were used as received.

\section{Phyto-constituents characterization}

Phytochemical screening refers to all methods and techniques for the detection of active chemical groups in the plant. In this study, the whole phytochemical screening was performed according to standard methods described by Badiaga et al (9). So, the presence of alkaloids has been revealed by Mayer or Dragendorff's reagent. STIANSY reagent or $1 \%$ ferric chloride was used to characterize tannin derivatives. Flavonoids derivatives and buffy anthocyanins were evidenced by the cyanidine reaction (SHINODA reagent). Quinone compounds were evidenced by the Bornträger reaction. The detection of sterols and triterpenes were possible with LiebermannBurchard reaction. Cardiotonic glycosides were revealed when green or purple color came out after adding the acetic and sulfuric acid in chloroformic extract. The appearance of a flaky precipitate revealed the presence of mucilages. Saponosides were characterized by their foaming power. Reducing constituents were characterized using $\mathrm{A}$ and $\mathrm{B}$ Fehling liquors. The anthracites derivatives were revealed using a $50 \%$ ammonia solution.

\section{Biological materials}

The bark of the trunk and the leaves of $H$. floribunda were harvested in March 2015 at Danyi Mountain in the plateaus region (Zone IV) of Togo. The plant is locally called "Afèkèti" or "Kpomiti" in "Ewé". It was (the plant species) identified by the Herbarium of "Universite de Lomé" (TOGO; TOGO02074) and previously registered under the identification number $1987 / 03$ by K. Akpagana (K. Akpagana, \#1522). The plant samples were left at room temperature for two weeks. After this drying process, the samples were reduced in powder using a lab scale grinder. Hydro-ethanolic extract of the trunk was prepared to assess pharmacological effects of $H$. floribunda on guinea pigs under normal blood pressure (systolic blood pressure $\leq 120 \mathrm{~mm} \mathrm{Hg}$ ) weighting about 400-550 g. They were bought in Gbonsimé market in Lomé city (Togo) and placed at animal house of the Laboratory of physiology and pharmacology of natural products of the Faculty of Sciences, "Université de Lomé" (Togo), for a week before the experiments. These guinea-pigs had free access to water and were fed with fresh grass.

Cardiovascular effects assessment via bloody method The so-called direct bloody method is an invasive technique for measuring blood pressure using a catheter introduced into the carotid artery of an anesthetized animal (10). The measurement of invasive pressure presents some advantages, notably the beat-by-beat tracking of blood pressure and the achievement of a very precise pressure even at very low extent. The invasive pressure was measured using a transducer (connected to the catheter) with an ultra-sensitive membrane capable of converting the slightest mechanical variations of the animal's blood pressure into electrical signals. The recording of the cardiovascular parameters was done according to this method exhaustively described previously (11). The guinea pig, anesthetized intraperitoneally with $20 \%$ of urethane (ethyl carbamate) at a dose of $1 \mathrm{~g} / \mathrm{kg}$ (that is 1 $\mathrm{mL} / 200 \mathrm{~g}$ body weight), was placed in supine position (12). The jugular vein and the carotid artery were exposed, dissected, and then intubated towards the heart using fine polyethylene catheters.

The catheter of the jugular vein connected to one syringe and that of the carotid artery linked to a pressure sensor connected to a transducer were used to visualize the hemodynamic parameters such as the systolic blood pressure (SBP, $\mathrm{mm} \mathrm{Hg}$ ) and the diastolic blood pressure (DBP, mm Hg). Those two types of blood pressure 
correspond to the maximum and the minimum pressures, respectively. Mean arterial pressure (MAP, $\mathrm{mmHg}$ ) does not an arithmetic average of SBP and DBP, because blood pressure values in the arteries are more closed to DBP value for a long time. For that, the average pressure was obtained from the following stated Pelletier' relation (13):

$$
M A P=D B P+\frac{(S B P-D B P)}{3}
$$

After stabilization of the cardiovascular parameters for about 45 minutes, the extracts of $H$. floribunda at cumulative doses of $10 ; 20 ; 40 ; 80 \mathrm{mg} / \mathrm{kg}$ (taking into account the toxicity studies of $H$. floribunda by Bogne et al (14) and Antwi (15)) were administered intravenously through the syringe connected to catheter of the jugular vein of a guinea pig under normal blood pressure. The $\mathrm{NaCl}$ solution (9\%o) containing $10 \%$ of heparin was injected at a rate of $1 \mathrm{~mL} / 1000 \mathrm{~g}$ via this jugular vein to prevent blood from clotting. The decrease rate in MAP was calculated using the following relation:

$\% \Delta \mathrm{MAP}=\left(\left(\mathrm{MAP}_{\mathrm{i}}-\mathrm{MAP}_{\mathrm{f}}\right) \times 100\right) /\left(\mathrm{MAP}_{\mathrm{i}}\right)$

With $i=$ initial; $f=$ final

Determination of total phenols and polyphenolic antioxidants

The determination of total phenols content is an in vitro colorimetric assay based on the ability to reduce the Folin-Ciocalteu reagent (FCR) (16) which is a yellow acid solution consisting of a mixture of phosphotungstic and phosphomolybdic polyheterocyclic acids. In a basic medium, the FCR oxidizes the hydroxyl groups of polyphenolic compounds giving a blue coloration. This determination was carried out according to the method described by Al-Farsi et al (17). A mixture consisting of $100 \mu \mathrm{L}$ of extract in methanol at $1 \mathrm{mg} / \mathrm{mL}$ and $750 \mu \mathrm{L}$ of the FCR 10 times diluted was prepared. After stirring for 5 minutes, $750 \mu \mathrm{L}$ of a saturated sodium carbonate $\left(\mathrm{Na}_{2} \mathrm{CO}_{3}\right)$ solution at $60 \mathrm{~g} / \mathrm{L}$ was added. The obtained solution was incubated for 90 minutes at room temperature in the darkness. The absorption spectra (optical densities) were recorded with respect to a blank at $725 \mathrm{~nm}$ using a UVvisible spectrophotometer. Referring to the calibration regression equation established with gallic acid in a concentration range of $0-500 \mu \mathrm{g} / \mathrm{mL}$ (Figure 1), the content of polyphenols in the extract was determined. The test was performed in triplicate. The following formula was used to calculate the total phenol contents expressed in mg Equivalent of Gallic Acid (EGA) over $1 \mathrm{~g}$ of dry extract:

\section{Polyphenol content $(E A G$ par $g)=$ \\ $\frac{\text { Rec.Conc } \times \text { Dil.Fact } \times \text { Vo }}{\text { sampl.mass }}$}

Rec.Conc: recorded concentration; Dil.Fac: dilution factor; Vo: initial volume; Sampl.mass: masse of the sample.
Free $\mathrm{DPPH} \cdot$ radical trapping activity

The antiradical activity was determined using the method described by Brand-Williams et al (18), modified by Agbonon et al (19). This method relies on the trapping of the stable free radical DPPH in the presence of antioxidant molecules.

The DPPH solution of about $10^{-4} \mathrm{~mol} / \mathrm{L}$ was prepared (about 1 to 2 hours in advance) by making soluble the pure DPPH in methanol so that the solution exhibited an optical density between 0.787 and 0.788 at $517 \mathrm{~nm}$. A range of concentrations ( 1 to $50 \mu \mathrm{g} / \mathrm{mL}$ ) of $H$. floribunda extract or quercetin solutions was prepared in methanol. A volume of $250 \mu \mathrm{L}$ of each of those prepared solutions was added to $1.5 \mathrm{~mL}$ of the DPPH solution $\left(\mathrm{C}=10^{-4} \mathrm{~mol} / \mathrm{L}\right)$, the mixture was homogenized and incubated at room temperature for 30 minutes. The optical density was then recorded at 517 nm using a UV-visible spectrophotometer. The control was recorded under the same conditions. The inhibition percent (\%I) of the DPPH was calculated according to the following formula:

$\% I=100 \times \frac{O D c-O D s}{O D c}$

ODc: Optical Density of the control; OD: Optical Density of the sample (extract or quercetin).

The anti-radical power was defined as the concentration of extract needed to induce the reduction of $50 \%$ of the free radical DPPH $\left(\mathrm{IC}_{50}\right)$. The $\mathrm{IC}_{50}$ value was calculated by the linear regression method shown in Figure 2: \% I = $\mathrm{f}($ concentration $)=\boldsymbol{a x}+\boldsymbol{b}$, with $\boldsymbol{a}$ and $\boldsymbol{b}$ constants and $\mathbf{x}$ a concentration; $\% \mathrm{I}=50 \%=\mathrm{f}\left(\mathrm{IC}_{50}\right)$. Standard deviations were calculated from three sets of experiments. The $\mathrm{IC}_{50}$ value depends on the nature of the sample and the final residual concentration of the DPPH.

\section{Antioxidant power by the FRAP}

The ferric ion reducing antioxidant power (FRAP) method consists of reducing ferric ions from the ferric tripyridyltriazine complex $\left(\mathrm{Fe}^{3+}-\mathrm{TPTZ}\right)$ to ferrous ions under a low $\mathrm{pH}$ and temperature of about $37^{\circ} \mathrm{C}$. The change in absorbance at $593 \mathrm{~nm}$ is directly associated with

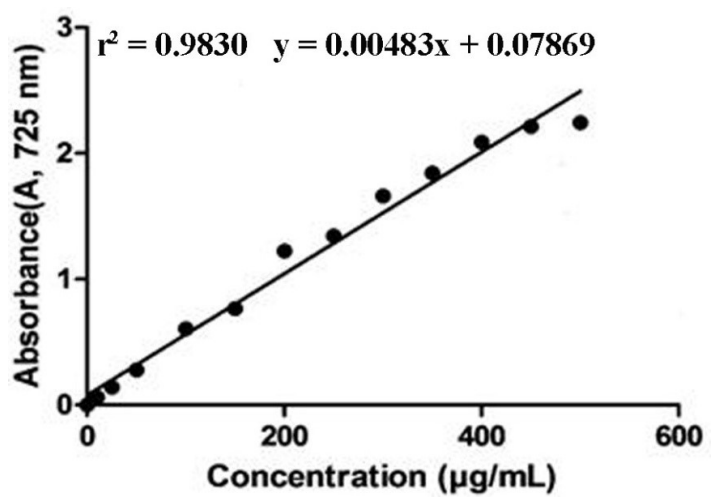

Figure 1. Calibration graph of gallic acid. 

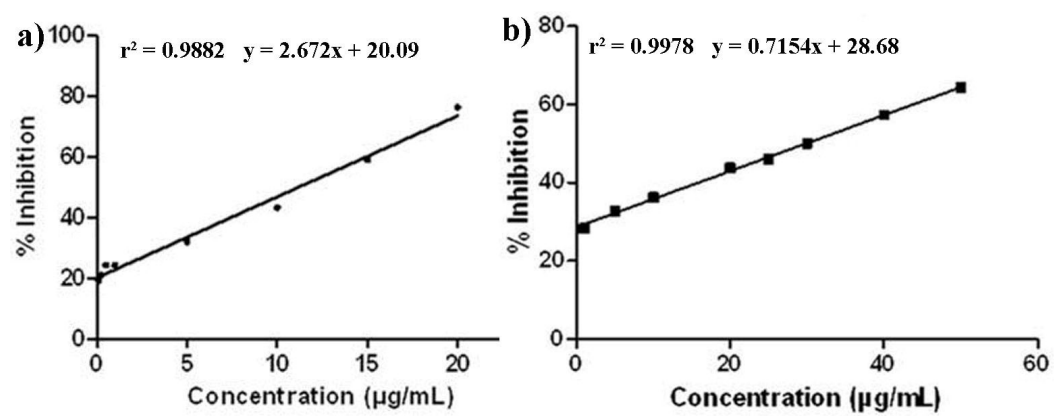

Figure 2: a) Linear regression line of quercetin, b) Linear regression line of Holarrhena floribunda extract with DPPH

the combined reducing power of all antioxidant molecules present in the reaction mixture (20).

For that, freshly prepared $1980 \mu \mathrm{L}$ FRAP solution consisting of $25 \mathrm{~mL}$ acetate buffer $(\mathrm{pH}=3.6), 2.5 \mathrm{~mL}$ TPTZ at $10 \mathrm{mmol} / \mathrm{L}$ in $\mathrm{HCl} 40 \mathrm{mmol} / \mathrm{L}$, and $2.5 \mathrm{~mL}$ of $\mathrm{FeCl}_{3} \cdot 6 \mathrm{H}_{2} \mathrm{O}$ at $20 \mathrm{mmol} / \mathrm{L}$, was added to $15 \mu \mathrm{L}$ of the extract solution. The optical densities of samples and blank at $593 \mathrm{~nm}$ were recorded using a UV-visible spectrophotometer. A calibration range was established from different concentrations ( 0 to $2000 \mu \mathrm{mol} / \mathrm{L}$ ) of $\mathrm{FeSO}_{4} \cdot 7 \mathrm{H}_{2} \mathrm{O}$ in methanol. Referring to the regression equation of the calibration established with $\mathrm{FeSO}_{4} \cdot 7 \mathrm{H}_{2} \mathrm{O}$ (Figure 3), the content of polyphenols in the extract was determined and expressed in $\mu$ mol of $\mathrm{Fe}^{2+}$ equivalent per gram of extract. The test was performed in triplicate from which the standard deviations were calculated. The concentration (content of polyphenols) of the stock solution was obtained using the following formula:

FRAP value ( $\mu$ mol equivalent $\mathrm{Fe}^{2+}$ per $\mathrm{g}$ ) =

$\underline{\text { Rec.Conc } \times \text { Dilut.Fact } \times \text { Vo }}$

\section{Sampl.Mass}

Rec.Conc: recorded concentration; Dilut.Fact: dilution factor; Vo: volume of the stock solution; Sampl.mass: mass of the sample.

\section{Statistical processing}

Data were expressed as means \pm standard deviation (SD) of experiments performed in triplicate or in quintuplicate according to the test. The values were analyzed by analysis of variance (ANOVA) test, followed by Tukey's multiple comparison tests using GraphPad Prism 5.00. The statistical significance between results for different samples and between results for samples and controls were set at $P<0.05$.

\section{Results}

Phytochemical screening of Holarrhena floribunda In order to investigate the phytochemical composition of $H$. floribunda, infusion, maceration, and decoction were used and many extracts obtained. For that, the leaves and bark of trunk powder samples were firstly subjected to infusion and decoction. The similar powder samples were then macerated in many organic solvents (ethanol, chloroform, hydrochloric acid, ethyl acetate, and petroleum ether). The various phytochemical groups detected in infused and decocted samples are recorded on the Table 1, and those from the maceration are drawn up in Table 2.

From infusion method (Table 1), one can see that anthocyanins were not detected. In the same time, tannins (catechics and gallic), saponosides, and flavonoids have been detected. From the decocted phases, the leucoanthocyanins, saponosides, mucilages, flavonoids, and reducing compounds were revealed in the two parts. Moreover, foam index performed on the decocted phase was 500 in the leaves against 333.33 in the trunk bark. In macerated samples and when using some specific tests, various phytochemical compounds were detected (Table 2). So, only alkaloids and saponosides were detected in ethanol while cardiotonic heterosides, c-heteroside, and o-heteroside anthracenic were found in chloroformic macerated phases. Alkaloids were found in hydrochloric acid; sterols and terpenes in ethyl acetate, and free quinones in petroleum.

Anti-radical activity by $\mathrm{DPPH}$, antioxidant power by FRAP and total phenol content

Based on the calibration regression equation established in Figure 1, the total phenol content (in equivalent of gallic acid per gram of dry extract) of the trunk bark hydro-ethanolic extract was $139 \pm 0.053 \mathrm{mg}$ EGA/g dry

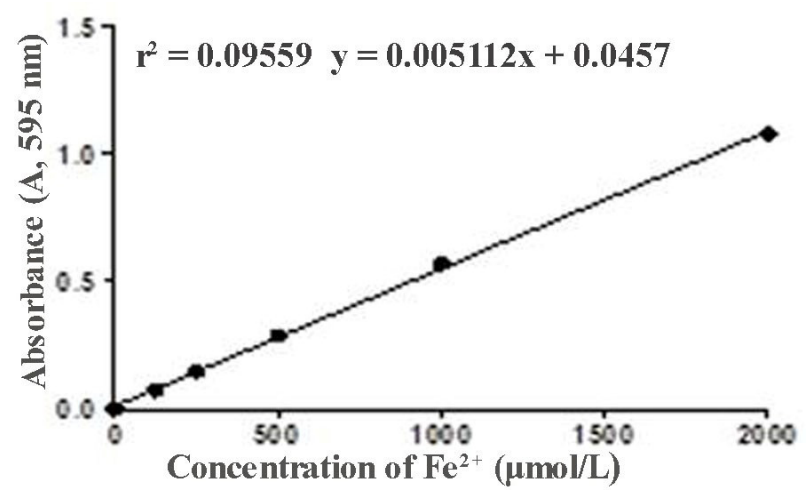

Figure 3. Calibration curve of $\mathrm{FeSO}_{4} \cdot 7 \mathrm{H}_{2} \mathrm{O}$ 
Table 1. Chemical groups detected in infuse and decocted powders of the leaves and the bark of the trunk

\begin{tabular}{llll}
\hline Extraction method & Phyto-constituents & Leaves & Trunk bark \\
\hline Infusion & Tannins & + & + \\
& Catechic tanins & + & + \\
& Gallic tannins & + & + \\
& Saponosides & + & + \\
& Flavonoids & + & - \\
& Anthocyanins & Leuco-anthocyanins & + \\
Decoction & Saponosides & + & + \\
& Foam Index & 500 & + \\
& Mucilages & + & + \\
& Flavonoids & + & + \\
& Reducing compounds & + & + \\
\end{tabular}

+: Detected; -: Not detected.

Table 2. Phyto-constituents from different macerated phases of leaves and trunk bark

\begin{tabular}{|c|c|c|c|}
\hline Extraction method & Phytoconstituents & Leaves & Bark of the trunk \\
\hline \multirow[t]{2}{*}{ Maceration in ethanol } & Alkaloids & + & + \\
\hline & Saponosides & + & + \\
\hline \multirow[t]{4}{*}{ Maceration in $\mathrm{CHCl}_{3}$} & Cardiovascular heterosides & + & + \\
\hline & Free anthracenic & - & - \\
\hline & Anthra.O-heterosides & + & + \\
\hline & Anthra.C-heterosides & + & + \\
\hline Maceration in $\mathrm{HCl}$ & Alkaloids & + & + \\
\hline Maceration in ethyl acetate & Sterols and terpenes & + & + \\
\hline Maceration in petroleum ether & Free quinones & + & + \\
\hline
\end{tabular}

+: Detected; -: Not detected.

extract. The antioxidant activity of the same extract was evaluated by the DPPH and the FRAP methods. The $\mathrm{DPPH}$ test allows getting the anti-radical activity. Indeed, it is known that an extract is more antioxidant if its $\mathrm{IC}_{50}$ is lower. From Table 3, the $\mathrm{IC}_{50}$ of this extract is $29.80 \pm 0.001$ $\mu \mathrm{g} / \mathrm{mL}$ while that of quercetin is $11.19 \pm 0.23 \mu \mathrm{g} / \mathrm{mL}$. The reducing power assessed by the FRAP method gave the value of $1009.9 \pm 0.6 \mu \mathrm{mol}$ Equivalent $\mathrm{Fe}^{2+} / \mathrm{g}$ (Table 3). Furthermore, the kinetics of the reduction of DPPH under different concentrations of the extract was monitored. As shown in Figure 4, the decrease in absorbance is more pronounced for large concentrated sample. The kinetic profiles are dependent on the concentration of the extract. Close observation shows that the extract reacted quickly with the DPPH reaching a steady state in about 5 minutes.

Assessment of the extract effect on guinea-pigs blood pressure

Intravenous injection of the hydro-ethanolic extract (by cumulative dose in the order of $10 ; 20 ; 40 ; 80 \mathrm{mg} / \mathrm{kg}$ )

Table 3. Results of DPPH and FRAP tests

\begin{tabular}{lll}
\hline Sample & IC50 $\pm S D(\mu \mathrm{g} / \mathrm{mL})$ & FRAP Equi.Fe ${ }^{2+}(\mu \mathrm{mol} / \mathrm{g})$ \\
\hline Extract & $29.80 \pm 0.001$ & $1009.9 \pm 0.6$ \\
Quercetin & $11.19 \pm 0.23$ & - \\
\hline
\end{tabular}

Values are expressed as means \pm standard deviation $(S D)(n=3)$. resulted in immediate decreases in mean arterial pressure (MAP) of normal strained guinea pigs (Figures 5 and 6). Indeed, a few seconds after injection of $10 \mathrm{mg} / \mathrm{kg}$ of the prepared dose, MAP decreased from $82.734 \mathrm{~mm} \mathrm{Hg}$ to $65.067 \mathrm{~mm} \mathrm{Hg}$, which is an immediate and significant decrease of about $21.35 \%$. Then, the pressure rose to hit the initial value in about 10 minutes later. Administering the dose of $20 \mathrm{mg} / \mathrm{kg}$ resulted in a sharp and significant decrease in MAP of about 27.86\%; 15 minutes later, the MAP rose and stabilized at about $70.6 \mathrm{~mm} \mathrm{Hg}$. The 40

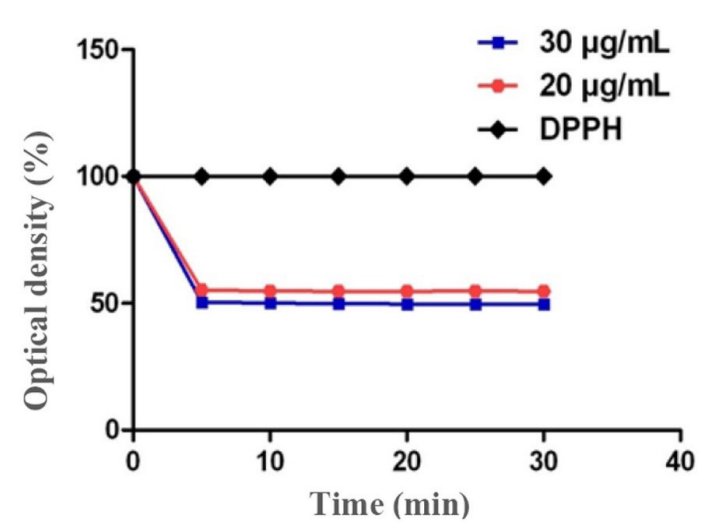

Figure 4. Kinetics of the reduction of the DPPH alone (black), DPPH with $20 \mu \mathrm{g} / \mathrm{mL}$ of Holarrhena floribunda extract (red), and DPPH with $30 \mu \mathrm{g} / \mathrm{mL}$ of Holarrhena floribunda extract (blue). 


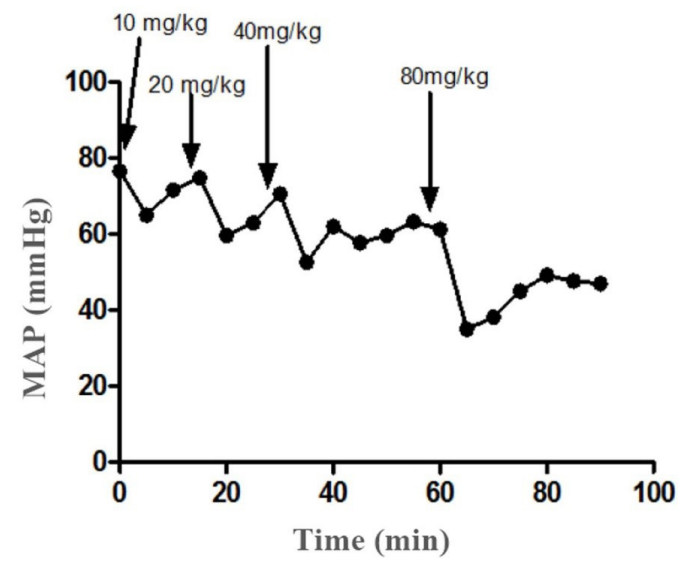

Figure 5. Effect of dose-response of Holarrhena floribunda extract on MAP.

$\mathrm{mg} / \mathrm{kg}$ dose resulted in a sharp and significant decrease in MAP of about $36.41 \%$; 20 minutes later the MAP rose and steadied at about $61.33 \mathrm{~mm} \mathrm{Hg}$. When $80 \mathrm{mg} / \mathrm{kg}$ was injected, a drastic and significant drop in MAP of about $57.68 \%$ was observed, 20 minutes later, the MAP rose slowly and steadied at about $47.67 \mathrm{~mm} \mathrm{Hg}$. It should be noted that the physiological solution of $\mathrm{NaCl} 9 \%$ with $10 \%$ of heparin had no significant effect on MAP (a variation of $0.025 \%$ has been obtained).

\section{Discussion}

First of all, the results of phytochemical screening of the leaves and the trunk bark confirmed the previous works of Badmus et al (21) and of Gnangoran et al (22). Indeed, most of the metabolites found in the current study possess significant pharmacological properties, including analgesics, anesthetics, antibiotics, and anticancer (23). For instance, plants containing flavonoids are known as potent antioxidants, antiradicals, diuretics, purgatives, disinfectants, analgesics, anti-inflammatories, antipyretics, and antispasmodics (24).

The revealed antioxidant properties (Table 3 ) of the hydro- ethanolic extract of the trunk bark of $H$. floribunda could have beneficial effects on the preventive treatment of CVD. Indeed, antioxidants have the ability to trap and inhibit the formation of free radicals. Flavonoids as antioxidants have effects on veins and arteries by decreasing permeability and increasing capillary resistance (23). It is known that the regular feeding of fruits and vegetables decreases the risk of developing CVD (25), as they contain antioxidants. According to the total polyphenols content and the screening study, the antioxidant properties might be mainly due to the presence of polyphenolic compounds such as tannins, flavonoids, and leuco-anthocyanins. Polyphenols are known as antioxidants and include five main families, namely phenolic acids, phenolic alcohols, flavonoids, tannins, and lignans (26). This work confirms that of Badmus et al (21) who showed that the leaves of $H$. floribunda possess antioxidant activity. Moreover, according to N'guessan et al (27), the anti-radical capacity is often correlated with the total polyphenols content of plant extracts. The result of the kinetics of the reduction obtained in the current study (Figure 4) is similar to those of Popovici et al (28). These observations show that the hydro-ethanolic extract of $H$. floribunda bark exhibited strong anti-radical efficiency.

The fall in MAP was based on the administered dose (Figures 5 and 6). Intravenous injection of the hydroethanolic extract of $H$. floribunda induced a significant decrease in DBP, in SBP, and thus in MAP. It should be noted that the dose of $40 \mathrm{mg} / \mathrm{kg}$ was seen as a best one (induce a better effect) because the return back effect under this dose is not only very slow but also weak. These results are somewhat similar to those obtained on the extracts of Bidens pilosa by Dimo et al (29) and Kouakou et al (30), and might be due to the presence of polyphenols, alkaloids, and saponosides in the current extract. The extract of $H$. floribunda therefore exhibits antihypertensive (hypothensive) effects, as shown in similar studies (12,31). Indeed, similar development has been obtained by Titrikou et al (12) on the extracts
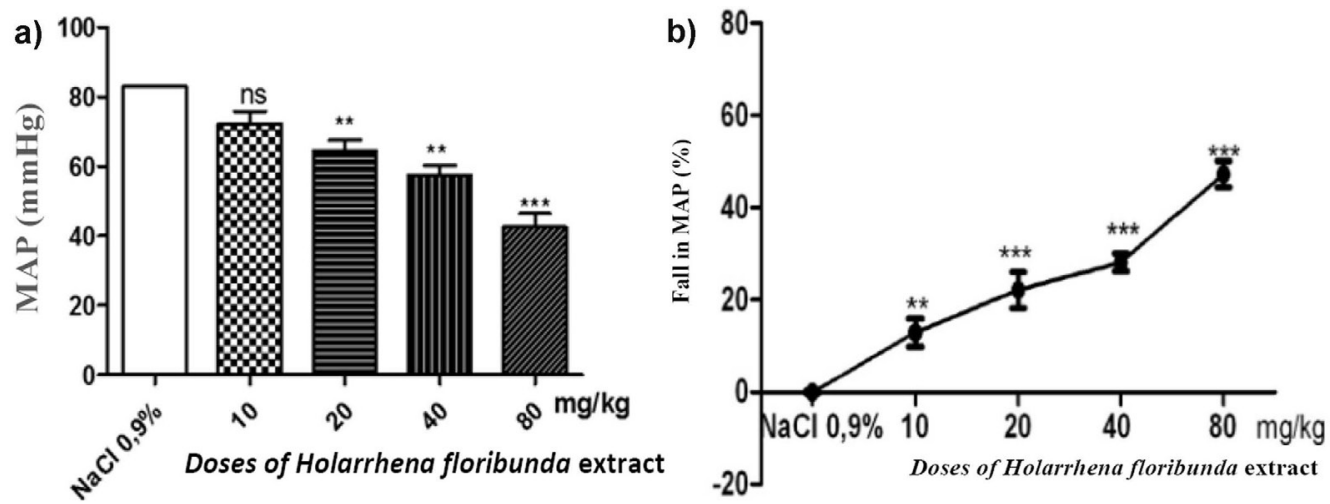

Figure 6. a) MAP of normal guinea pigs development under $\mathrm{NaCl} 9 \%$ and doses of Holarrhena floribunda extract 15 minutes after injection; b) Impact of $\mathrm{NaCl} 9 \%$ and extract of Holarrina floribunda on fall in MAP of normal guinea pigs. Each point represents an average \pm SD (standard deviation). With $n=5,{ }^{*} P<0,05 ;{ }^{* *} P<0,01$ and ${ }^{* * *} P<0,001$ significantly different compared to the initial value of the MAP. 
of Biophytum petersianum and Etou et al (31) on the extracts of Lippia multiflora. Furthermore, the possible mechanisms involved in this positive effect (hypothensive) could be an inhibition of orthosympathetic activity or a decrease in oxidative stress. Indeed, an increase in oxidative stress is observed in hypertensive patients (32). The polyphenols content in this extract might play a key role in inhibiting the action of activated oxygen species. Moreover, the antidiabetic activity of $H$. floribunda (22) might also have positive preventive effects, by improving the insulin sensitivity.

\section{Conclusion}

This study showed the presence of various active phytochemical groups in the bark of the trunk and the leaves of $H$. floribunda specimen of the Zone IV of Togo. So, the phytochemical screening revealed alkaloids, tannins (catechics, gallic), flavonoids, leucoanthocyanins, saponosides, free quinones, anthrax Cand O-heterosides), reducing compounds, mucilages, cardiotonic heterosides, sterols, and terpenoids in the two parts of $H$. floribunda. The hydro-ethanolic extract of the trunk bark of $H$. floribunda exhibited in vitro antioxidant activity and in vivo antihypertensive effect. The two observations might prove the use of $H$. floribunda extract in traditional medicine against cardiocardiovascular diseases. However, further study might be envisaged in order to elucidate the mechanism of action of the observed effects. This could provide strong pharmacological arguments that converge in favor of the use of $H$. floribunda as an alternative treatment against high blood pressure (hypertension). In the same way, it might be very interesting to carry out a more thorough phytochemical study in the hope of isolating some active principles responsible for this hypotensive activity.

\section{Author Contributions}

KK, ETK, and OS conducted the full work. PB, OT, and NYG participated in the writing process. KT, AA, and MG gave technical support via the availability and the using of the Biopac System Apparatus. They also participated in the writing process. All authors have approved the submission of this paper.

\section{Conflict of interests}

Authors declare no conflict of interests.

\section{Ethical considerations}

The project was done with consideration of ethical issues and obtaining license from the ethics committee of local institute (Université de Lomé in Togo has a branch of National Ethic Committee that approved the experimental protocols using World Health Organization guidelines for the care and use of laboratory animals). Also, the general care of the experimental animals used for this study was done in compliance with the Animal Welfare Act.

\section{Acknowledgements}

The authors are grateful to Laboratory of Botany and Plant Ecology of the Faculty of Sciences, "Université de Lomé" (Togo), especially to his head Professor Koffi Akpagana, for the help in identification of the plant.

\section{References}

1. Gaziano T. Prevention and treatment of chronic diseases in developing countries, Population Division of United Nations, Department of Economic and Social Affairs. Expert Paper No. 2011/2, 2011.

2. WHO. Maladies cardiovasculaires. http://www.who.int/ mediacentre/factsheets/fs317/fr/. Accessed January 2015.

3. National Program for the Fight against Non-Transmissible Diseases-TOGO (PNMNT-TOGO). Integrated strategic plan for non-transmissible diseases for 2012-2015. PNMNT-TOGO; 2012.

4. Kearney PM, Whelton M, Reynolds K, Muntner P, Whelton PK, He J. Global burden of hypertension: analysis of worldwide data. Lancet. 2005;365(9455):217-23. doi: 10.1016/s0140-6736(05)17741-1.

5. Girouard H, Chulak C, LeJossec M, Lamontagne D, de Champlain J. Chronic antioxidant treatment improves sympathetic functions and beta-adrenergic pathway in the spontaneously hypertensive rats. J Hypertens. 2003;21(1):179-88. doi: 10.1097/01. hjh.0000045536.21915.1a.

6. Asgary S, Sahebkar A, Afshani MR, Keshvari M, Haghjooyjavanmard S, Rafieian-Kopaei M. Clinical evaluation of blood pressure lowering, endothelial function improving, hypolipidemic and anti-inflammatory effects of pomegranate juice in hypertensive subjects. Phytother Res. 2014;28(2):193-9. doi: 10.1002/ptr.4977.

7. Arbonnier M. Arbres, arbustes et lianes des zones sèches d'Afrique de l'Ouest. Cirad, Mnhn, Uicn, 573p, 2002.

8. Arbonnier M. Arbres, arbustes et lianes des zones sèches d'Afrique de l'Ouest. http://www.quae.com/en/r1281arbres-arbustes-et-lianes-des-zones-seches-d-afrique-de-louest.html. 2009. Accessed 13 March 2009.

9. Badiaga M. Etude ethnobotanique, phytochimique et activités biologiques de Nauclea latifolia Smith, une plante médicinale africaine récoltée au Mali. $\mathrm{PhD}$ thesis, University of Blaise Pascal - Clermont-Ferrand II, 2011. NNT:2011CLF22187.

10. Van Vliet BN, Chafe LL, Antic V, Schnyder-Candrian S, Montani JP. Direct and indirect methods used to study arterial blood pressure. J Pharmacol Toxicol Methods. 2000;44(2):361-73.

11. Ngelefack TB, Mekhfi H, Dimo T, Afkir S, NguelefackMbuyo EP, Legssyer A, et al. Cardiovascular and anti-platelet aggregation activities of extracts from Solanumtorvum (Solanaceae) fruits in rat. J Complement Integr Med. 2008;5(1):1-11. doi: 10.2202/1553-3840.1105.

12. Titrikou S, Eklu-Gadegbeku K, Aklikokou KA, Gbeassor M. Effets de Biophytum petersianum (Oxalidaceae) sur la pression artérielle chez le rat Wistar. [Effects of Biophytum petersianum (Oxalidaceae) on arterial blood pressure in 
Wistar rats]. Phytotherapie. 2008;6(4):215-8. doi: 10.1007/ s10298-008-0321-3.

13. Pelletier A. Origine métabolique et effets des nucléotides extracellulaires sur le système circulatoire du cobaye. Méd Trad Afr. 1998;17(1):1-9.

14. Bogne KP, Penlap BV, Mbofung CM, Etoa FX. Acute and subacute toxicity of the methanol extract from Holarrhena floribunda G. Don (Apocynaceae). Euro J Exp Biol. 2012;2(4):1284-8.

15. Antwi S. Evaluation of the anti-inflammatory effects of the hydroethanolic extract of Holarrhena floribunda in Murine Models of inflammation [Master Thesis]. Kumasi : Kwame Nkrumah University of Science and Technology (Ghana); 2015.

16. Singleton VL, Orthofer R, Lamuela-Raventos RM. Analysis of total phenols and other oxidation substrates and antioxidants by means of Folin-Ciocalteu Reagen. Methods Enzymol. 1999;299C(1):152-78. doi: 10.1016/S00766879(99)99017-1.

17. Al-Farsi M, Alasalvar C, Morris A, Baron M, Shahidi F. Comparison of antioxidant activity, anthocyanins, carotenoids, and phenolics of three native fresh and sundried date (Phoenix dactylifera L.) varieties grown in Oman. J Agric Food Chem. 2005;53(19):7592-9. doi: 10.1021/ jf050579q.

18. Brand-Williams W, Cuvelier ME, Berset C. Use of a free radical method to evaluate antioxidant activity. LWT Food Sci Technol. 1995;28(1):25-30. doi: 10.1016/S00236438(95)80008-5.

19. Agbonon A, Gbeassor M. Hepatoprotective Effect of Lonchocarpus sericeus Leaves in CCl4- Induced Liver Damage. J Herbs Spices Med Plants. 2009;15(2):216-26. doi: 10.1080/10496470903139512.

20. Benzie IF, Strain JJ. The ferric reducing ability of plasma (FRAP) as a measure of "antioxidant power": the FRAP assay. Anal Biochem. 1996;239(1):70-6. doi: 10.1006/ abio.1996.0292.

21. Badmus JA, Ekpo OE, Rautenbach F, Marnewick JL, Hussein AA, Hiss DC. Isolation and antioxidant activity of flavonoids from Holarrhena floribunda (G.don) leaves. Acta Biochim Pol. 2016;63(2):353-8. doi: 10.18388/ abp.2015_1178.

22. Gnangoran BN, N'guessan BB, Amoateng P, Dosso K, Yapo AP, Ehile EE. Hypoglycemic activity of ethanolic leaf extract and fractions of Holarrhena floribunda (Apocynaceae). J Med Biomedical Sci. 2012;1(3):46-54.

23. Bruneton J. Pharmacognosie, Plantes Médicinales. Paris:
Lavoisier Technique et Documentation; 1999:405.

24. Ngene JP, Ngoule CC, Pouka Kidik CM. Importance dans la pharmacopée traditionnelle des plantes à flavonoïdes vendues dans les marchés de Douala est (Cameroun). J Appl Biosci.2015;88:8194-210. doi: 10.4314/jab.v88i1.6.

25. Hertog MG, Feskens EJ, Hollman PC, Katan MB, Kromhout D. Dietary antioxidant flavonoids and risk of coronary heart disease: the Zutphen Elderly Study. Lancet. 1993;342(8878):1007-11.

26. Saloufou $\mathrm{K}$. Teneur en composés phénoliques et pouvoir Antioxydant des extraits de cinq plantes Médicinales de la flore togolaise [Master thesis]. Lomé : Université de Lomé; 2013.

27. N'guessan JD, Zirihi GN, Kra AKM, Kouakou K, Djaman AJ, Guede-Guina F. Free radical scavenging activity, flavonoid and phenolic contents of selected Ivoirian plants. International Journal of Natural and Applied Sciences. 2007;3(4):425-9. doi: 10.4314/ijonas.v3i4.36155.

28. Popovici C, Saykova I, Tylkowski B. Evaluation de l'activité antioxydant des composés phénoliques par la réactivité avec le radical libre DPPH. Revue de Génie Industriel. 2009;4:25-39.

29. Dimo T, Nguelefack TB, Tan PV, Yewah MP, Dongo E, Rakotonirina SV, et al. Possible mechanisms of action of the neutral extract from Bidens pilosa L. leaves on the cardiovascular system of anaesthetized rats. Phytother Res. 2003;17(10):1135-9. doi: 10.1002/ptr.1132.

30. Kouakou LK, Traore F, Abo JCK, Ehile EE. Effets pharmacologiques d'un extrait aqueux de Bidens pilosa L.(Asteraceae) sur le système cardiovasculaire de mammifères. [Pharmacological effects of an aqueous extract of Bidens pilosa L. ( Asteraceae ) on the cardiovascular system of mammals]. Afrique Science. 2007;3(2):284-304. doi: $\quad 10.4314 /$ afsci.v3i2.61275

31. Etou-Ossibi AW, Elion-Itou RD, Nzonzi J, Nsonde Ntandou GF, Dimo T, Ouamba JM, et al. Effets de l'extrait aqueux de Lippia multiflora Moldenke (Verbenaceae) sur la pression artérielle, la fréquence cardiaque et les ondes de lélectrocardiogramme chez le rat normotendu. [Effects of aqueous extract of Lippia multiflora Moldenke (Verbenaceae) on the blood pressure, the heart rate and onelectrocardiogramwaves at the normotensive rat]. Revue CAMES-Série Pharm Méd Trad Afr. 2014;17(1):1-9.

32. Rodrigo R, Prat H, Passalacqua W, Araya J, Guichard C, Bachler JP. Relationship between oxidative stress and essential hypertension. Hypertens Res. 2007;30(12):115967. doi: 10.1291/hypres.30.1159. 